Article

\title{
Selective Arylation of
}

\section{2-Bromo-4-chlorophenyl-2-bromobutanoate via a} Pd-Catalyzed Suzuki Cross-Coupling Reaction and Its Electronic and Non-Linear Optical (NLO) Properties via DFT Studies

\author{
Usman Nazeer 1,2, Nasir Rasool 1,* Aqsa Mujahid ${ }^{1}$, Asim Mansha ${ }^{1}$, Muhammad Zubair ${ }^{1}$, \\ Naveen Kosar ${ }^{3}$, Tariq Mahmood ${ }^{3}$, Ali Raza Shah ${ }^{1}$, Syed Adnan Ali Shah 4,5 ${ }^{1}$,
}

Zainul Amiruddin Zakaria $6,7, *$ (D) and Muhammad Nadeem Akhtar ${ }^{8,9}$

1 Department of Chemistry, Government College University, Faisalabad 38000, Punjab, Pakistan; usmannazeer1187@gmail.com (U.N.); aqsamujahid99@yahoo.com (A.M.); mansha.asim@gmail.com (A.M.); zubairmkn@yahoo.com (M.Z.); razagcu756@gmail.com (A.R.S.)

2 College of Chemistry and Molecular Engineering, Zhengzhou University, Kexue road No. 100, Zhengzhou 450001, China

3 Department of Chemistry, COMSATS University Islamabad, Abbottabad Campus, University Road, Tobe Camp, Abbottabad 22060, Pakistan; naveenflavia@gmail.com (N.K.); mahmood@cuiatd.edu.pk (T.M.)

4 Faculty of Pharmacy, Universiti Teknologi MARA Cawangan Selangor Kampus Puncak Alam, Bandar Puncak Alam 42300, Malaysia; syedadnan@uitm.edu.my

5 Atta-ur-Rahman Institute for Natural Products Discovery (AuRIns), Universiti Teknologi MARA Cawangan Selangor Kampus Puncak Alam, Bandar Puncak Alam 42300, Malaysia

6 Department of Biomedical Science, Faculty of Medicine and Health Sciences, Universiti Putra Malaysia, Serdang 43400, Malaysia

7 Halal Institute Research Institute, Universiti Putra Malaysia, Serdang 43400, Malaysia

8 Faculty of Industrial Sciences \& Technology, Universiti Malaysia Pahang, Lebuhraya Tun Razak, Gambang Kuantan 26300, Malaysia; nadeemupm@gmail.com

9 Bio-Aromatic Research Center of Excellence, Faculty of Industrial Sciences \& Technology, Universiti Malaysia Pahang, Lebuhraya Tun Razak, Gambang Kuantan 26300, Malaysia

* Correspondence: nasirrasool@gcuf.edu.pk (N.R.); zaz@upm.edu.my (Z.A.Z.); Tel.: +92-332-749-1790 (N.R.); +603-8947-2111 (Z.A.Z.); Fax: +92-419-201-032 (N.R.); +603-8943-6178 (Z.A.Z.)

Academic Editors: M. Graça P. M. S. Neves and Gianfranco Favi

Received: 29 May 2020; Accepted: 15 July 2020; Published: 31 July 2020

\begin{abstract}
In the present study, 2-bromo-4-chlorophenyl-2-bromobutanoate (3) was synthesized via the reaction of 2-bromo-4-chlorophenol with 2-bromobutanoyl bromide in the presence of pyridine. A variety of 2-bromo-4-chlorophenyl-2-bromobutanoate derivatives $(\mathbf{5 a}-\mathbf{f})$ were synthesized with moderate to good yields via a Pd-catalyzed Suzuki cross-coupling reaction. To find out the reactivity and electronic properties of the compounds, Frontier molecular orbital analysis, non-linear optical properties, and molecular electrostatic potential studies were performed.
\end{abstract}

Keywords: suzuki cross coupling; frontier molecular orbital analysis; molecular electrostatic potential; non-linear optical properties

\section{Introduction}

Carboxylic esters are an important class of organic compounds, having various biological activities such as antifungal [1], antioxidant [2], anti-inflammatory [3], antiproliferative [4], and anti-bacterial [5], and they have been widely used in the biofuel [6], plasticizer [7], food, and cosmetic industries [8]. 
In natural product chemistry, esters are well known common intermediates because of their accessibility for easy interconversion and their stability. Esters are generally synthesized by the condensation of carboxylic acids with alcohols. Moreover, activation of the carboxyl group followed by reaction with suitable alcohol is one of the most familiar methods for ester formation [9]. Similarly, biphenyl compounds are used as central building blocks for basic liquid crystal [10] and fluorescent layers in organic light-emitting diodes (OLEDs) [11] and are also important pharmaceutically as anti-hypertensive [12], anti-inflammatory [13], potential anti-cholinesterase [14], anti-diabetic [15], anti-tumor [16], anti-cancer [17], and anti-leukemia agents [18], and as potential therapeutics for cardiovascular disease [19] and osteoporosis [20].

For the synthesis of biphenyl compounds, the Suzuki-Miyaura reaction is one of the best methods. In organic synthesis, regioselective functionalization plays a progressively important role [21]. In such types of reactions, the reaction takes place at the carbon atom, which is more electron-deficient, while the other active site remains unattached. This concept has been practiced in region-selective Pd-catalyzed cross-coupling reactions based on different rates of oxidative additions of Pd (0) species to carbon halide bonds of different substrates. Therefore, we focused on the synthesis of 2-bromo-4-chlorophenyl-2-bromobutanoate followed by regioselective arylation of 2-bromo-4-chlorophenyl-2-bromobutanoate via a palladium-catalyzed Suzuki-Miyaura cross-coupling reaction to obtain the 2-bromo-4-chlorophenyl-2-bromobutanoate derivatives. Frontier molecular orbital (FMO), non-linear optic properties (NLO) and molecular electrostatic potential (MEP) studies were performed to find out the most reactive site of the compound.

\section{Results and Discussion}

\subsection{Chemistry}

In the present study, 2-bromo-4-chlorophenyl-2-bromobutyrate (3) was synthesized by the reaction of 2-bromo-4-chlorophenol (1) with 2-bromobutryl bromide (2) in the presence of pyridine and acetonitrile, and good yield of 2-bromo-4-chlorophenyl-2-bromobutyrate (3) was observed (Scheme 1).<smiles>CCC(Br)C(=O)Br</smiles>

Scheme 1. Synthesis of 2-bromo-4-chlorophenyl-2-bromobutyrate (3). Conditions: (i) 1 (1 g, 4.820 $\mathrm{mmol}), 2$ (0.64 mL, $5.3 \mathrm{mmol})$, pyridine $(0.7 \mathrm{~mL}, 9.63 \mathrm{mmol}), \mathrm{MeCN}(30 \mathrm{~mL}), 0{ }^{\circ} \mathrm{C}, 1 \mathrm{~h}$.

In addition, the Suzuki-Miyaura cross-coupling reaction of 2-bromo-4-chlorophenyl-2-bromo butyrate (3) with different phenyl boronic acids was accomplished, which ultimately led to the formation of the corresponding 2-bromo-4-chlorophenyl-2-bromobutyrates (5a-f) in moderate to good yields (64-81\%) (Scheme 2, Table 1). When 1.1 eq of phenyl boronic acid was used, it was noted that the bromo group of the phenyl group was replaced, while in the presence of $\mathrm{Pd}\left(\mathrm{PPh}_{3}\right)_{4}$, the other bromo group present at the alpha position could not be replaced. The chloro group at the phenyl ring was not replaced due to the $\mathrm{C}-\mathrm{Cl}$ bond strength that obstructs the reactivity of aryl chlorides, thus, they are resistant to the oxidative addition to $\operatorname{Pd}(0)$ because activation of aryl chlorides is much more difficult than that of aryl bromides. The oxidative addition step is a selectivity-determining step in Suzuki cross-coupling, and it is broadly controlled by the bond dissociation energies of the carbon-halogen bond that predictably differs as a function of the aryl halides: $\mathrm{Ar}-\mathrm{I}>\mathrm{Ar}-\mathrm{Br}>\mathrm{Ar}-\mathrm{Cl}>\mathrm{Ar}-\mathrm{F}$ [22]. It was 
noted that phenyl boronic acids having electron-donating substituents gave high yields as compared to electron-withdrawing substituted phenyl boronic acids.<smiles>CCC(Br)C(=O)Oc1ccc(Cl)cc1Br</smiles>

Scheme 2. Synthesis of 2-aryl-4-chlorophenyl-2-bromobutyrates (5a-f). Conditions: (i) 3 (200 mg, 0.062 mmol, 1 eq), 4 (0.683 mmol, $1.1 \mathrm{eq}), \mathrm{Pd}\left(\mathrm{PPh}_{3}\right)_{4}(35 \mathrm{mg}, 5 \mathrm{~mol} \%), \mathrm{K}_{3} \mathrm{PO}_{4}(263 \mathrm{mg}, 1.24 \mathrm{mmol}, 2.2 \mathrm{eq}), 1$, 4-dioxane $(8 \mathrm{~mL})$, water $(4 \mathrm{~mL}), 90{ }^{\circ} \mathrm{C}, 17 \mathrm{~h}$ under argon.

Table 1. Suzuki-Miyaura reaction of 2-bromo-4-chlorophenyl-2-bromobutyrate with different phenyl boronic acids.

Sr. No. Phenyl Boronic Acid Solvent/ $\mathrm{H}_{2} \mathrm{O}$ (4:1) Yield \%


Table 1. Cont.

Sr. No. Phenyl Boronic Acid

\subsection{Frontier Molecular Orbital Analysis}

Frontier molecular orbital (FMO) analysis is well known to explain the reactivity and electronic properties of the molecules [23]. The energies of HOMOs $\left(\mathrm{E}_{\mathrm{HOMO}}\right)$ and LUMOs $\left(\mathrm{E}_{\mathrm{LUMO}}\right)$ provide information about the electronic transition and the HOMOs-LUMOs gap $\left(\mathrm{G}_{\mathrm{H}-\mathrm{L}}\right)$ explains the reactivity and kinetic stability of the compounds. If the $\mathrm{G}_{\mathrm{H}-\mathrm{L}}$ is low, the compound will be less stable and more reactive, but if the $\mathrm{G}_{\mathrm{H}-\mathrm{L}}$ is large, the compound will be highly stable and less reactive [24]. The energies of HOMOs ( $\left.\mathrm{E}_{\mathrm{HOMO}}\right)$, energies of LOMOs $\left(\mathrm{E}_{\mathrm{LUMO}}\right)$, and the highest occupied molecular orbital to lowest unoccupied molecular orbital gap $\left(\mathrm{G}_{\mathrm{H}-\mathrm{L}}\right)$ are summarized in Table 2.

Table 2. The energies of HOMOs ( $\mathrm{E}_{\mathrm{HOMO}}$, in eV), energies of LUMOs ( $\mathrm{E}_{\mathrm{LUMO}}$, in $\mathrm{eV}$, $)$ HOMOs-LUMOs gap $\left(\mathrm{G}_{\mathrm{H}-\mathrm{L}}\right)$, and dipole moment ( $\mu$, in Debye) of compounds $(\mathbf{5 a}-\mathbf{f})$.

\begin{tabular}{cccc}
\hline Compounds & E $_{\text {HOMOs }}$ & E LUMOs & G $_{\text {H-L }}$ \\
\hline $\mathbf{5 a}$ & -7.06 & -1.93 & 5.14 \\
$\mathbf{5 b}$ & -7.03 & -1.97 & 5.06 \\
$\mathbf{5 c}$ & -6.06 & -1.79 & 4.27 \\
$\mathbf{5 d}$ & -7.07 & -1.98 & 5.09 \\
$\mathbf{5 e}$ & -6.30 & -1.73 & 4.57 \\
$\mathbf{5 f}$ & -7.06 & -1.87 & 5.19 \\
\hline
\end{tabular}

Among all compounds, compound $5 \mathrm{c}$ has the lowest $\mathrm{G}_{\mathrm{H}-\mathrm{L}}(4.27 \mathrm{eV})$ where the $\mathrm{E}_{\mathrm{HOMOs}}$ and $\mathrm{E}_{\mathrm{LUMO}}$ were -6.06 and $-1.79 \mathrm{eV}$, respectively. Based on the lower $\mathrm{G}_{\mathrm{H}-\mathrm{L}}, \mathbf{5 c}$ is considered as kinetically less stable and moderately reactive. Compound $5 \mathbf{f}$ has $\mathrm{G}_{\mathrm{H}-\mathrm{L}}$ of $5.19 \mathrm{eV}$, which showed it is the most stable and least reactive of the whole series $(\mathbf{5 a}-\mathbf{f})$. The $\mathrm{G}_{\mathrm{H}-\mathrm{L}}$ of the other compounds were between 4.57 and $5.14 \mathrm{eV}$, which represent their moderate reactivity and sufficient stability. Although the $\mathrm{G}_{\mathrm{H}-\mathrm{L}}$ of $5 \mathrm{c}$ is low, compared to other compounds, it is large.

The iso-density distributions in the FMOs of all compounds were also shown in Figure 1. In all the compounds (except compounds $\mathbf{5} \mathbf{c}$ and $\mathbf{5 e}$ ), the iso-density of HOMOs was distributed on the phenyl rings and halogen (chlorine and fluorine) groups that were present on the phenyl rings. However, this iso-density of HOMOs is shifted from the chlorine-containing phenyl ring towards the MeS- and $\mathrm{MeO}$-groups containing phenyl rings in compounds $\mathbf{5 c}$ and $\mathbf{5 e}$, respectively. This specific distribution explains the lower iso-density of $\mathbf{5} \mathbf{c}$ and $\mathbf{5 e}$ compared to that of the other compounds. The shift of iso-density is more pronounced for $\mathbf{5 c}$ in comparison to $5 \mathbf{e}$. The iso-density of LUMOs is mostly distributed on the bromo-ester group attached to the phenyl ring in all compounds $(\mathbf{5 a}-\mathbf{f})$. 


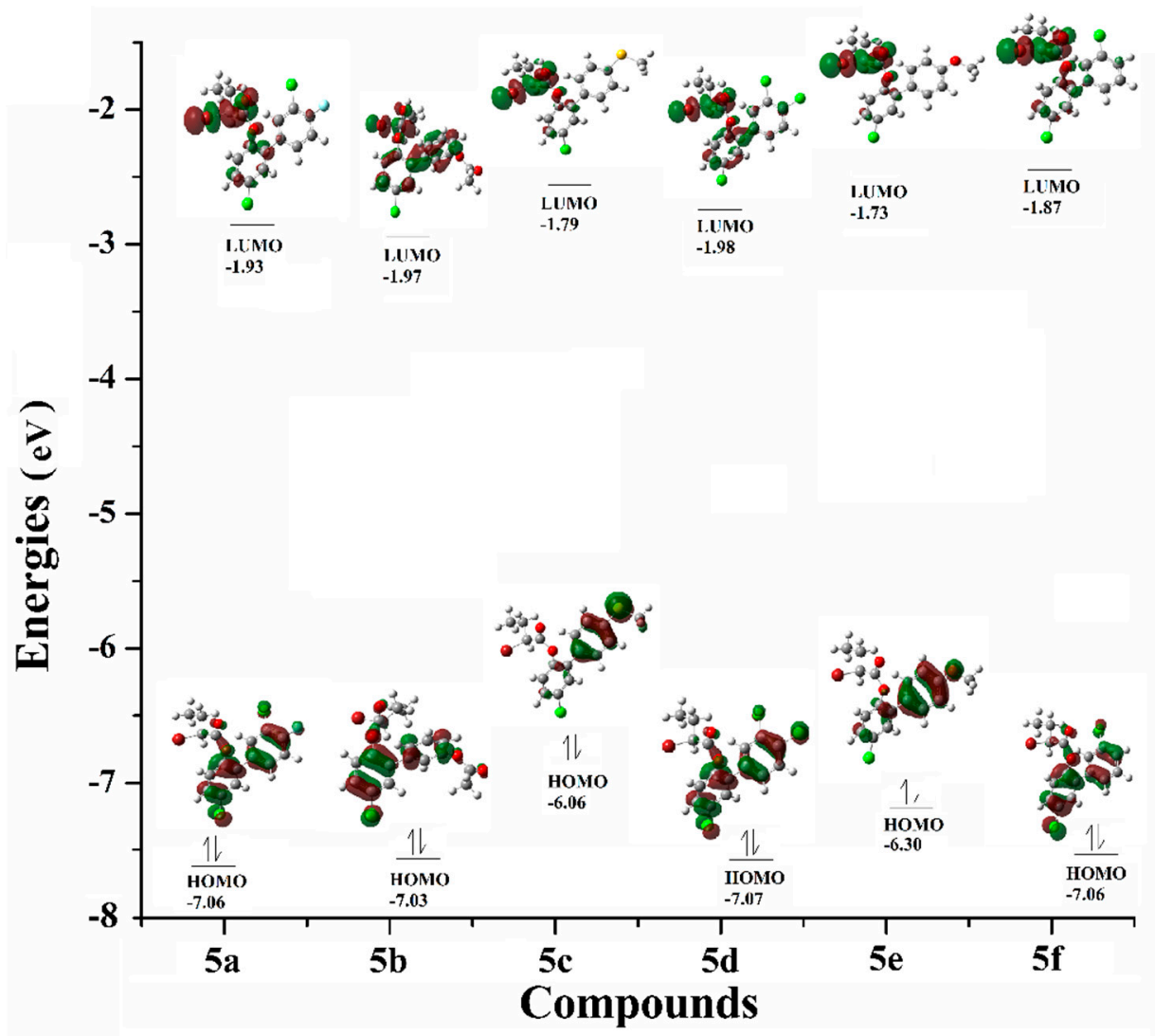

Figure 1. FMOs plot of all compounds (5a-f) based on the relative energies; the energies are in $\mathrm{eV}$.

\subsection{Reactivity Descriptor Parameters}

For further elucidation of the reactivity of these compounds $(\mathbf{5 a}-\mathbf{f})$, some other reactivity descriptor parameters were also studied. The results of the analyses are given in Table 3. These parameters include ionization potential $(I)$, electrophilicity index $(\mathrm{\omega})$, nucleophilicity $(\mathrm{N})$, electron affinity $\left(E_{A}\right)$, electronic chemical potential $(\mu)$, and chemical hardness (П). According to Koopman's theorem, the negative of HOMOs and LUMOs values correspond to the ionization potential $(I)$ and electron affinity $\left(E_{A}\right)$, respectively [25].

Table 3. Ionization potential $(I)$, electron affinity $\left(E_{A}\right)$, chemical hardness $(\eta)$, electronic chemical potential $(\mu)$, electrophilicity index $(\mathrm{C})$, and nucleophilicity $(\mathrm{N})$ of compounds $(\mathbf{5 a}-\mathbf{f})$. All values are given in $\mathrm{eV}$.

\begin{tabular}{|c|c|c|c|c|c|c|}
\hline Compounds & $\begin{array}{l}\text { Ionization } \\
\text { Potential (I) }\end{array}$ & $\begin{array}{c}\text { Electron } \\
\text { Affinity }\left(E_{A}\right)\end{array}$ & $\begin{array}{c}\text { Chemical } \\
\text { Hardness }(\eta)\end{array}$ & $\begin{array}{c}\text { Electronic Chemical } \\
\text { Potential }(\mu)\end{array}$ & $\begin{array}{l}\text { Electrophilicity } \\
\text { Index (C) }\end{array}$ & $\begin{array}{l}\text { Nucleophilicity } \\
\text { (N) }\end{array}$ \\
\hline $5 a$ & 7.06 & 1.93 & 2.57 & -4.50 & 3.94 & 5.14 \\
\hline $5 b$ & 7.03 & 1.97 & 2.53 & -4.50 & 4.00 & 5.06 \\
\hline $5 c$ & 6.06 & 1.79 & 2.13 & -3.92 & 3.61 & 4.27 \\
\hline $5 d$ & 7.07 & 1.98 & 2.55 & -4.52 & 4.02 & 5.09 \\
\hline $5 e$ & 6.30 & 1.73 & 2.29 & -4.01 & 3.52 & 4.57 \\
\hline $5 f$ & 7.06 & 1.87 & 2.60 & -4.46 & 3.83 & 5.19 \\
\hline
\end{tabular}

2.3.1. Ionization Potential, Electron Affinity, and Chemical Hardness ( 1 )

The Chemical hardness is mathematically expressed as:

$$
\text { Chemical hardness }(\eta)=\left(E_{\text {HOMO }}-E_{\text {LUMO }}\right) / 2
$$


The values obtained for all compounds from different reactivity descriptor are comparable and support each other, which strengthens our findings. The ionization potential of all compounds was in the range of $6.06 \mathrm{eV}$ to $7.06 \mathrm{eV}$. The most reactive and unstable compound in this series was $\mathbf{5 c}$, and its reactivity was also supported from its lower ionization potential $(I=6.06 \mathrm{eV})$, electron affinity $\left(E_{A}=1.79 \mathrm{eV}\right)$, and chemical hardness $(\eta=2.13 \mathrm{eV})$ values. The compound $5 \mathrm{f}$ was the most stable compound, which is also confirmed from its high $I(7.06 \mathrm{eV})$ and $\eta(2.60 \mathrm{eV})$ values. The chemical hardness of the other compounds was between 2.13 and $2.57 \mathrm{eV}$.

\subsubsection{Electronic Chemical Potential $(\mu)$}

The electronic chemical potential gives us an idea about the charge transfer inside compounds at their ground state, and it is mathematically expressed as:

$$
\text { Electronic chemical potential }(\mu)=\left(\mathrm{E}_{\mathrm{HOMO}}+\mathrm{E}_{\mathrm{LUMO}}\right) / 2
$$

The electronic chemical potential $(\mu)$ of all compounds $(\mathbf{5 a}-\mathbf{f})$ was in the range of $-3.92 \mathrm{eV}$ to $-4.52 \mathrm{eV}$. The highest $\mu(-4.52 \mathrm{eV})$ value was observed for $5 \mathbf{d}$ and the lowest $\mu$ value $(-3.92 \mathrm{eV})$ was calculated for $5 \mathrm{c}$.

\subsubsection{Electrophilicity Index (c)}

Parr et al. provided the concept of the electrophilicity index (c) [26], which is mathematically expressed as:

$$
\text { Electrophilicity index }(\omega)=\mu 2 / n
$$

According to this concept, the $\omega$ is the stabilization of a compound based on energy when an additional charge is transferred from the surroundings or outside environment. The $c$ ranged from $3.52 \mathrm{eV}$ to $4.02 \mathrm{eV}$ for compounds $5 \mathbf{a}-\mathbf{f}$. The compound $5 \mathbf{e}$ had the lowest $\mathrm{c}$ value $(3.52 \mathrm{eV})$ in the series of compounds, which indicates that this compound is less stable for an incoming charge. The reason is the electronic acceptor and donor groups present in the compound are connected through extended conjugation. The incoming charge causes further delocalization of electronic density in the compound and enhances its reactivity.

\subsubsection{Nucleophilicity (N)}

Nucleophilicity is derived from HOMOs and LUMOs values by using the following mathematical equation:

$$
\text { Nucleophilicity }(\mathrm{N})=\mathrm{E}_{\mathrm{HOMO}}-\mathrm{E}_{\mathrm{LUMO}}
$$

Nucleophilicity is an important parameter for understanding the reactivity of compounds. All the compounds had nucleophilicity values in the range of $4.27 \mathrm{eV}$ to $5.19 \mathrm{eV}$. The compound $5 \mathrm{c}$ had the lowest $N$ value $(4.27 \mathrm{eV})$, which represents the soft nucleophilic nature of this compound. Whereas compound 3'5-Dichloro-[1,1'-biphenyl]-2-yl 2-bromobutanoate (5f) has the highest $N$ value $(5.19 \mathrm{eV})$, which shows the strong nucleophilic nature of this compound.

\subsection{Molecular Electrostatic Potential (MEP)}

Molecular electrostatic potential (MEP) is used to evaluate and predict the reactive sites of a molecule [27]. MEP is generated on the surfaces of all optimized compounds to explain the nucleophilic and electrophilic sites. The potentials on the surfaces of complexes are characterized by various colors and are described in increasing order of red $<$ orange $<$ yellow $<$ green $<$ blue. The green colors show the neutral region while red and blue colors are used for the nucleophilic and electrophilic sites of the complex, respectively. The molecular electrostatic surfaces of all compounds are given in Figure 2 and the values are given in Table 4. 


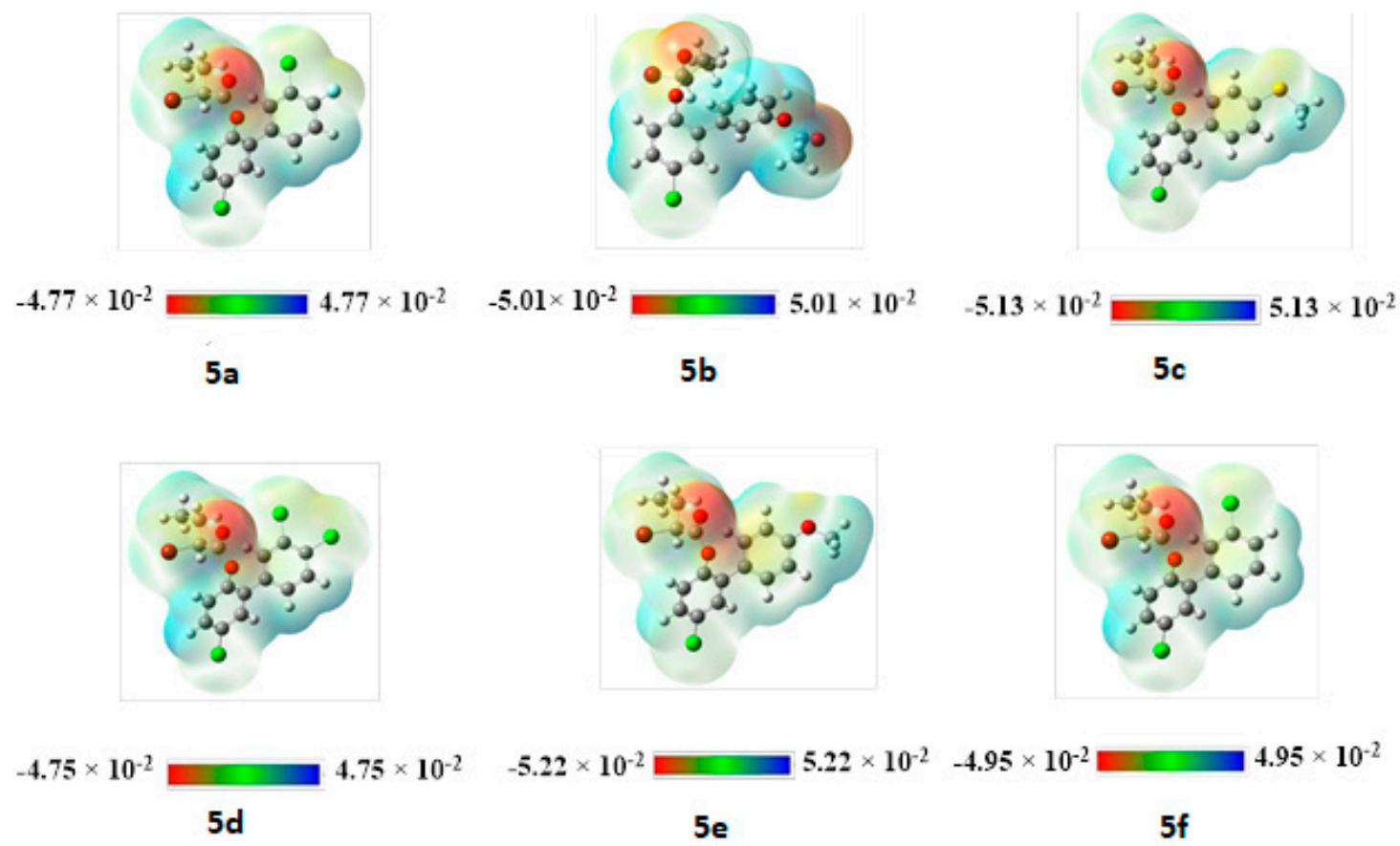

Figure 2. Molecular electrostatic potential surfaces of compounds (5a-f), the electronic density in red represents nucleophilic sites and in blue represents electrophilic site.

Table 4. Molecular electrostatic potential (MEP) values of all compounds (5a-f).

\begin{tabular}{ccc}
\hline Compounds & -ve Potential & +ve Potential \\
\hline $\mathbf{5 a}$ & $-4.77 \times 10^{-2}$ & $4.77 \times 10^{-2}$ \\
$\mathbf{5 b}$ & $-5.01 \times 10^{-2}$ & $5.01 \times 10^{-2}$ \\
$\mathbf{5} \mathbf{c}$ & $-5.13 \times 10^{-2}$ & $5.13 \times 10^{-2}$ \\
$\mathbf{5 d}$ & $-4.75 \times 10^{-2}$ & $4.75 \times 10^{-2}$ \\
$\mathbf{5 e}$ & $-5.22 \times 10^{-2}$ & $5.22 \times 10^{-2}$ \\
$\mathbf{5 f}$ & $-4.95 \times 10^{-2}$ & $4.95 \times 10^{-2}$ \\
\hline
\end{tabular}

Figure 2 indicates that the ester group attached to the phenyl ring is an active site for an incoming electrophile. Whereas, hydrogen attached to the phenyl rings have blue electronic densities that represent the strong nucleophilic site. Yellow densities reside on the $\mathrm{S}$ atom of the $\mathrm{MeS}, \mathrm{O}$ of the $\mathrm{MeO}$, $\mathrm{Cl}$, and $\mathrm{F}$ atoms, illustrating the moderately electrophilic sites of these functional groups. The highest electronic density distribution of $-4.75 \times 10^{-2}$ to $4.75 \times 10^{-2}$ was observed for compound $5 \mathrm{~d}$. In contrast, the lowest electronic density distribution of $-5.22 \times 10^{-2}$ to $5.22 \times 10^{-2}$ was observed for compound $5 \mathbf{e}$.

\subsection{Non-linear Optical (NLO) Properties}

For the last decade, scientific society has been pursuing the pathways to synthesized non-linear optical (NLO) materials with large second-order nonlinear optical properties. Non-linear optical materials have various applications in laser devices, optical communication, optical data storage, optical limiting, optical computing, and medical imaging [28,29]. The NLO response of these materials is measured by the first hyperpolarizability $\left(\beta_{\mathrm{o}}\right)$. In organic molecules, the movement of electrons from donor to acceptor group is responsible for the enhancement of $\beta_{0}$, which ultimately results in a strong NLO response. 
In the synthesized compounds (5a-f), the para chloro-phenyl ring ( $p$-CPR) acts as electronwithdrawing group and influences different substitutions on the NLO response were studied at the ortho position of phenyl ring. The ester group is not involved due to the resonance between the two oxygen atoms and the electrons are unable to delocalize inside the phenyl ring. When the electron donating groups are attached to the $p-C P R$, the electron push full mechanism is the operative one and a large $\beta_{0}$ value is obtained. However, if the electron-withdrawing groups are attached to the $p$-CPR, then the electron push full mechanism is not operating and the small $\beta_{\mathrm{O}}$ value is obtained in that case. The compound $5 \mathrm{c}$ has a strong electron donating group (MeS-) at the para position of the phenyl ring and we noticed a large $\beta_{\mathrm{o}}$ value (1373.76 au) for it according to the push full mechanism. The lower $\beta_{\mathrm{o}}$ value (218.51 au) was observed for compound $5 \mathrm{f}$ where an electron-withdrawing chloro group $\left(\mathrm{Cl}^{-}\right)$is present on the para position of the phenyl ring. On both sides of the phenyl rings, similar chloro-groups are attached which make these rings strongly electron-withdrawing, and the net effect is zero. The moderate electron donating methoxy group at the para position of the phenyl ring (in 5e) had a reasonable NLO response compared to compound $\mathbf{5 b}$ where the acetate group has an internal resonance, which has a negative impact on the NLO response. The $\beta_{\mathrm{o}}$ values of $\mathbf{5 e}$ and $\mathbf{5 b}$ compounds were $954.47 \mathrm{au}$ and $284.34 \mathrm{au}$, respectively. Compounds $\mathbf{5 a}$ and $\mathbf{5 d}$ had almost comparable $\beta_{\mathrm{o}}$ values (in the range of $510 \mathrm{au}-550 \mathrm{au}$ ). The reason may be that the presence of halogen groups on the meta and para positions of the ring nullified the effects of each other and the phenyl ring acted as moderately electron-donating. Based on these results, we suggest that compound $5 \mathrm{c}$ shows a better NLO response and can be used as an active NLO material in the future.

The hyperpolarizability of these compounds ( $\mathbf{5 a}-\mathbf{f})$ was also supported by the polarizability values (Table 5). Polarizability is defined as the electronic density distribution in a system. In compounds where electron-accepting and electron-donating groups are present at the opposite termini of the phenyl rings, they must have positive and negative centers and their $\alpha_{0}$ is high. In contrast, in those compounds where both termini have similar functional groups, there is an equal distribution of electronic density and $\alpha_{\mathrm{o}}$ is low. For example, compound $\mathbf{5 c}$ had a high $\alpha_{\mathrm{o}}$ value (264 au) whereas $\mathbf{5 f}$ had a low $\alpha_{\mathrm{o}}$ value (235 au). The rest of the compounds had moderate values of $\alpha_{\mathrm{o}}$ in the range of 236 au to 252 au.

Table 5. Polarizability $\left(\alpha_{\mathrm{O}}\right)$ and hyperpolarizability $\left(\beta_{\mathrm{O}}\right)$ of compounds $\mathbf{5 a}-\mathbf{f}$ with CAM-B3LYP and LC-BLYP methods.

\begin{tabular}{ccccc}
\hline \multirow{2}{*}{ Compounds } & \multicolumn{2}{c}{ CAM-B3LYP } & \multicolumn{2}{c}{ LC-BLYP } \\
& $\boldsymbol{\alpha}_{\mathbf{o}}$ & $\boldsymbol{\beta}_{\mathbf{o}}$ & $\boldsymbol{\alpha}_{\mathbf{o}}$ & $\boldsymbol{\beta}_{\mathbf{o}}$ \\
\hline $\mathbf{5 a}$ & 236 & 515.43 & 229 & 436.87 \\
$\mathbf{5 b}$ & 252 & 284.34 & 244 & 223.17 \\
$\mathbf{5 c}$ & 264 & 1373.76 & 255 & 1010.54 \\
$\mathbf{5 d}$ & 250 & 539.03 & 243 & 445.12 \\
$\mathbf{5 e}$ & 244 & 954.47 & 237 & 776.21 \\
$\mathbf{5 f}$ & 235 & 218.51 & 228 & 173.78 \\
\hline
\end{tabular}

Non-linear Refractive Index $\left(\mathrm{n}_{2}\right)$

The quadratic non-linear refractive index $\left(n_{2}\right)$ was calculated by using degenerated four waves mixing gamma values $\left(\gamma^{\mathrm{DFWM}}(\omega)=(-\omega ; \omega,-\omega, \omega)\right.$ as proposed by Tarazker et al. [30] and it is mathematically expressed as follows:

$$
\gamma^{\mathrm{DFWM}}(-\omega ; \omega,-\omega, \omega)=(1 / 3) \gamma(-2 \omega ; \omega, \omega, 0)+(1 / 3) \gamma(-\omega ; \omega, 0,0)+(1 / 3) \gamma(0 ; 0,0,0)
$$


where $\gamma(0 ; 0,0,0), \gamma(-\omega ; \omega, 0,0)$, and $\gamma(-2 \omega ; \omega, \omega, 0)$ represent static, dc-Kerr, and EFSHG second hyperpolarizability coefficients, respectively. The $\gamma^{\mathrm{DFWM}}$ is further used to measure the quadratic non-linear refractive index $\left(n_{2}\right)$ using Equation 6.

$$
n_{2}\left(\mathrm{~cm}^{2} / \mathrm{W}\right)=8.28 \times 10^{-23} \gamma^{\mathrm{DFWM}}(\mathrm{au})
$$

The $n_{2}$ values of all compounds $(5 \mathbf{a}-\mathbf{f})$ at various frequencies $(0,532$ and $1064 \mathrm{~nm})$ are given in Table 6 and graphically represented in Figure 2. In the spectral curves of $n_{2}$, the ESHG effect and dc-Kerr effect are similar and demonstrate the dominant contribution of both these effects in enhancing $n_{2}$ (Figure 3). However, the effect of the ESHG effect is more pronounced as compared to that of the dc-Kerr effect. The $n_{2}$ values for compounds (5a-f) were in the range $8.01 \times 10^{-18}$ au to $9.46 \times 10^{-16}$ au at $\omega=532 \mathrm{~nm}$. These compounds have $n_{2}$ values in the range of $4.43 \times 10^{-18}$ au to $8.41 \times 10^{-18}$ au at $\omega=1064 \mathrm{~nm}$. Among all compounds, the distinct effect was noticed at a low wavelength (532 nm) where the highest value $\left(9.46 \times 10^{-16} \mathrm{au}\right)$ was noticed for compound $5 \mathrm{c}$. These $n_{2}$ values proved the influence of various wavelengths on the amplitude of hyperpolarizability and gamma values of these compounds. Besides the various wavelengths, the structure of the compounds also plays a substantial role in the fluctuation of the NLO response. The structure of compound $5 \mathrm{c}$ has electron donating and electron withdrawing groups on both terminals of the main skeleton and an excellent push-pull mechanism occurs due to extended conjugation, and its NLO response is outstanding. This result is also supported by the nonlinear refractive index results.

Table 6. The static, dc-Kerr effect, electric field-induced second harmonic generation coefficients (in au), and quadratic non-linear refractive index $\left(n_{2}=\mathrm{cm}^{2} / \mathrm{W}\right)$ at different wavelengths (in $\mathrm{nm}$ ) for compounds $(5 \mathbf{a}-\mathbf{f})$.

\begin{tabular}{|c|c|c|c|c|c|}
\hline Compounds & Frequency & $\gamma(0 ; \mathbf{0}, \mathbf{0}, \mathbf{0})$ & $\gamma(-\omega ; \omega, \omega, 0)$ & $\gamma(-2 \omega ; \omega, \omega, 0)$ & $n_{2}$ \\
\hline & 0 & 48741.5 & & & \\
\hline \multirow[t]{3}{*}{$5 a$} & 532 & & 64320.8 & 199529 & $8.63 \times 10^{-18}$ \\
\hline & 1064 & & 51988.4 & 59645.3 & $4.43 \times 10^{-18}$ \\
\hline & 0 & 54142.2 & & & \\
\hline \multirow[t]{3}{*}{$5 b$} & 532 & & 73258.1 & 293432 & $1.16 \times 10^{-17}$ \\
\hline & 1064 & & 58215.3 & 67505.4 & $4.96 \times 10^{-18}$ \\
\hline & 0 & 86291.9 & & & \\
\hline \multirow[t]{3}{*}{$5 c$} & 532 & & 141361 & 34064301 & $9.46 \times 10^{-16}$ \\
\hline & 1064 & & 95936.8 & 122589 & $8.41 \times 10^{-18}$ \\
\hline & 0 & 57794.5 & & & \\
\hline \multirow[t]{3}{*}{$5 d$} & 532 & & 78682.2 & 314130 & $1.24 \times 10^{-17}$ \\
\hline & 1064 & & 61860 & 72208.8 & $5.3 \times 10^{-18}$ \\
\hline & 0 & 63232 & & & \\
\hline \multirow[t]{3}{*}{$5 e$} & 532 & & 92924.8 & 1013010.1 & $3.23 \times 10^{-17}$ \\
\hline & 1064 & & 69085.6 & 83451.7 & $5.96 \times 10^{-18}$ \\
\hline & 0 & 49285.2 & & & \\
\hline \multirow[t]{2}{*}{$5 f$} & 532 & & 64440.9 & 176408 & $8.01 \times 10^{-18}$ \\
\hline & 1064 & & 52669.5 & 60014.7 & $4.47 \times 10^{-18}$ \\
\hline
\end{tabular}



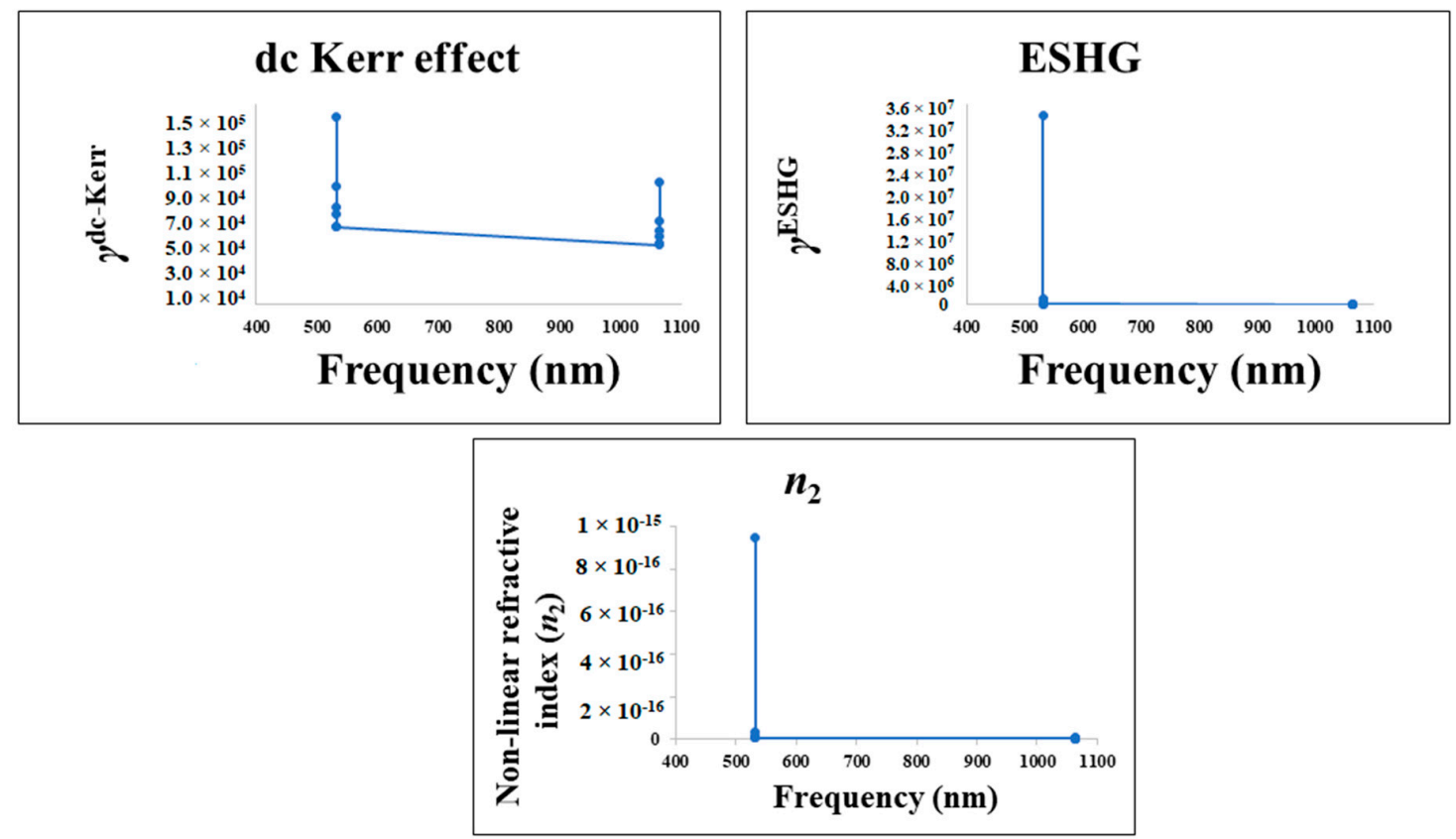

Figure 3. Graphical representations of dc-Kerr, ESHG coefficients, and refractive index for compounds (5a-f) at different wavelengths (532 and $1064 \mathrm{~nm}$ ).

\section{Materials and Methods}

\subsection{Procedure for Synthesis of 2-Bromo-4-chlorophenyl-2-bromobutyrate (3)}

First, 2-Bromo-4-chlorophenol ( $1 \mathrm{~g}, 4.820 \mathrm{mmol}), \mathrm{MeCN}(30 \mathrm{~mL})$, pyridine $(0.775 \mathrm{~mL}, 9.63 \mathrm{mmol})$, and 2-bromobutryl bromide $(0.64 \mathrm{~mL}, 5.3 \mathrm{mmol})$ were added to a $250 \mathrm{~mL}$ round bottom flask with a magnetic stirrer. The flask's mouth was closed with a Teflon septum. The flask was put on the magnetic hot plate along with an isotherm to maintain the temperature of the reaction mixture at $0{ }^{\circ} \mathrm{C}$. The progress of the reaction was estimated by thin layer chromatography analysis. After $1 \mathrm{~h}$, the reaction was completed. The separation and purification of the desired product was carried out using the column chromatography technique. The NMR spectroscopic technique was used to find out the structure of the desired compound [31].

2-Bromo-4-chlorophenyl 2-bromobutanoate (3), yellow liquid, ${ }^{1} \mathrm{H}-\mathrm{NMR}$ : $\left(600 \mathrm{MHz}, \mathrm{CDCl}_{3}\right) \delta 7.9$ (d, $J=1.5 \mathrm{~Hz}, 1 \mathrm{H}), 7.50\left(\mathrm{dd}, J_{1}=7.5 \mathrm{~Hz}, J_{2}=1.5 \mathrm{~Hz}, 1 \mathrm{H}\right), 7.29(\mathrm{~d}, J=7.5 \mathrm{~Hz}, 1 \mathrm{H}), 4.29(\mathrm{t}, J=7.1 \mathrm{~Hz}, 1 \mathrm{H})$, 2.05-2,10 (m, 2H, Ar), $1.1(\mathrm{t}, J=8.0 \mathrm{~Hz}, 3 \mathrm{H}) .{ }^{13} \mathrm{C}-\mathrm{NMR}\left(150 \mathrm{MHz}, \mathrm{CDCl}_{3}\right) \delta 10.1\left(\mathrm{CH}_{3}\right), 24.1\left(\mathrm{CH}_{2}\right)$, $42.7(\mathrm{CH}), 115.2(\mathrm{C}), 117.6(\mathrm{CH}), 121.3(\mathrm{CH}), 129.4(\mathrm{CH}), 139.5(\mathrm{C}), 145.5(\mathrm{C}), 170.2(\mathrm{C}) . \mathrm{HR}-\mathrm{ESI}-\mathrm{MS}: \mathrm{m} / \mathrm{z}$ Calcd for $\mathrm{C}_{10} \mathrm{H}_{9} \mathrm{Br}_{2} \mathrm{ClO}$, [M] $]^{+} 353.8909$; found 353.8945 .

\subsection{General Procedure for Synthesis of $(5 \boldsymbol{a}-f)$}

A reflux condenser flushed with argon was attached to a $100 \mathrm{~mL}$ schlenk flask with a magnetic stirrer. Then, 2-bromo-4-chlorophenyl-2-bromobutyrate (1 equiv.) and tetrakis(triphenyl phosphine)palladium(0) (5 equiv.) were added to the schlenk flask and dissolved into $8 \mathrm{~mL}$ of 1,4-dioxane and the flask's mouth was closed with a Teflon septum. The reaction mixture was stirred for about 25-30 min under an inert argon atmosphere. Then, $\mathrm{K}_{3} \mathrm{PO}_{4}$ (2 equiv.) and aryl boronic acids and $2 \mathrm{~mL}$ distilled water were added and the reflux reaction continued under an inert argon atmosphere for $18-25 \mathrm{~h}$ at $80-90{ }^{\circ} \mathrm{C}$. During the reaction, the estimation of the reaction was determined by a thin layer chromatography technique using TLC cards. When the reaction was completed, the reaction mixture was filtered using Whatman filter paper and the solvent was evaporated by a rotary evaporator. The separation and purification of the impure products were carried out using 
the column chromatography technique. ${ }^{1} \mathrm{H}-\mathrm{NMR}$ was used to find out the structure of the newly synthesized compounds [32].

3'5-Dichloro-4'-fluoro-[1,1'-biphenyl]-2-yl 2-bromobutanoate (5a), white crystals, m.p. $247-248^{\circ} \mathrm{C} .{ }^{1} \mathrm{H}-\mathrm{NMR}$ $\left(600 \mathrm{MHz}, \mathrm{CDCl}_{3}\right) 8.04(\mathrm{~d}, J=1.8 \mathrm{~Hz}, 1 \mathrm{H}), 8.00(\mathrm{~d}, J=1.5 \mathrm{~Hz} 1 \mathrm{H}), 7.55\left(\mathrm{dd}, J_{1}=1.6 \mathrm{~Hz}, J_{2}=7.7 \mathrm{~Hz}\right.$, $1 \mathrm{H}), 7.41\left(\mathrm{dd}, J_{1}=7.7 \mathrm{~Hz}, J_{2}=8.0 \mathrm{~Hz} 1 \mathrm{H}\right), 7.38(\mathrm{~d}, J=8.1 \mathrm{~Hz}, 1 \mathrm{H}), 7.35(\mathrm{~m}, 1 \mathrm{H}), 4.2(\mathrm{t}, J=7.0 \mathrm{~Hz}, 1 \mathrm{H})$, 2.11-2.17 (m, 2H, Ar), $1.11(\mathrm{t}, J=7.5 \mathrm{~Hz}, 3 \mathrm{H}) .{ }^{13} \mathrm{C}-\mathrm{NMR}\left(150 \mathrm{MHz}, \mathrm{CDCl}_{3}\right) \delta 10.2\left(\mathrm{CH}_{3}\right), 25.4\left(\mathrm{CH}_{2}\right)$, $42.7(\mathrm{CH}), 117.6(\mathrm{CH}), 122.4(\mathrm{C}), 125.6(\mathrm{CH}), 130.5(\mathrm{CH}), 131.6(\mathrm{CH}), 132.5(\mathrm{CH}), 133.2(\mathrm{CH}), 132.9(\mathrm{C})$, 133.4 (C), 133.9 (C), 148.1 (C), 162.3 (C), 170.1 (C). HR-ESI-MS: $m / z$ Calcd for $\mathrm{C}_{16} \mathrm{H}_{12} \mathrm{BrCl}_{2} \mathrm{FO}_{2}$, [M] 406.0722; found 406.0742.

3'-Acetoxy-5-chloro-[1, 1'-biphenyl]-2-yl 2-bromobutanoate (5b), yellow crystals, m.p: $268-269{ }^{\circ} \mathrm{C} .{ }^{1} \mathrm{H}-\mathrm{NMR}$ $\left(600 \mathrm{MHz}, \mathrm{CDCl}_{3}\right) \delta 8.00(\mathrm{~d}, J=2.0 \mathrm{~Hz}, 1 \mathrm{H}), 7.50\left(\mathrm{dd}, J_{1}=7.9 \mathrm{~Hz}, J_{2}=1.8 \mathrm{~Hz}, 1 \mathrm{H}\right), 7.46(\mathrm{~d}, J=1.5 \mathrm{~Hz}$, $1 \mathrm{H}), 7.42-7.34(\mathrm{~m}, 2 \mathrm{H}), 7.35\left(\mathrm{dd}, J_{1}=7.7 \mathrm{~Hz}, J_{2}=1.5 \mathrm{~Hz}, 1 \mathrm{H}\right), 7.28(\mathrm{~d}, J=7.5 \mathrm{~Hz}, 1 \mathrm{H}), 4.20(\mathrm{t}, J=7.0 \mathrm{~Hz}$, $1 \mathrm{H}), 2.35(\mathrm{~s}, 3 \mathrm{H}), 2.10-2.15(\mathrm{~m}, 2 \mathrm{H}, \mathrm{Ar}), 1.10(\mathrm{t}, J=7.9 \mathrm{~Hz}, 3 \mathrm{H}) .{ }^{13} \mathrm{C}-\mathrm{NMR}\left(150 \mathrm{MHz}, \mathrm{CDCl}_{3}\right) \delta 10.1\left(\mathrm{CH}_{3}\right)$, $19.4\left(\mathrm{CH}_{3}\right), 25.6\left(\mathrm{CH}_{2}\right), 45.4(\mathrm{CH}), 120.4(\mathrm{CH}), 121.1(\mathrm{CH}), 122.3(\mathrm{CH}), 128.7(\mathrm{CH}), 129.1(\mathrm{CH}), 131.2$ (C), $132.7(\mathrm{CH}), 134.8(\mathrm{CH}), 136.3(\mathrm{C}), 137.5(\mathrm{C}), 145.1$ (C), 148.1 (C), 170.1 (C), 171.2 (C). HR-ESI-MS: $\mathrm{m} / \mathrm{z}$ Calcd for $\mathrm{C}_{18} \mathrm{H}_{16} \mathrm{BrClO}_{4},[\mathrm{M}]^{+}$411.6808; found 411.6892 .

5-Chloro-4'-(methylthio)-[1,1'-biphenyl]-2-yl 2-bromobutanoate (5c), brown crystals, m.p: $250-251{ }^{\circ} \mathrm{C}$. ${ }^{1} \mathrm{H}-\mathrm{NMR}\left(600 \mathrm{MHz}, \mathrm{CDCl}_{3}\right) \delta 8.00(\mathrm{~d}, J=1.9 \mathrm{~Hz}, 1 \mathrm{H}), 7.65(\mathrm{~d}, J=8.2 \mathrm{~Hz}, 2 \mathrm{H}), 7.45(\mathrm{~d}, J=7.9 \mathrm{~Hz}, 2 \mathrm{H})$, $7.35\left(\mathrm{dd}, J_{1}=7.5 \mathrm{~Hz}, J_{2}=2.0 \mathrm{~Hz}, 1 \mathrm{H}\right), 7.25(\mathrm{~d}, J=8.4 \mathrm{~Hz}, 1 \mathrm{H}), 4.19(\mathrm{t}, J=7.0 \mathrm{~Hz}, 1 \mathrm{H}), 2.53(\mathrm{~s}, 3 \mathrm{H})$, 2.05-2.11 (m, 2H, Ar), $1.10(\mathrm{t}, J=7.0 \mathrm{~Hz}, 3 \mathrm{H}) .{ }^{13} \mathrm{C}-\mathrm{NMR}\left(150 \mathrm{MHz}, \mathrm{CDCl}_{3}\right) \delta 10.1\left(\mathrm{CH}_{3}\right), 19.4\left(\mathrm{CH}_{3}\right)$, 25.6 $\left(\mathrm{CH}_{2}\right), 45.4(\mathrm{CH}), 121.1(\mathrm{CH}), 124.3(\mathrm{CH}), 125.4(2 \mathrm{CH}), 128.1(\mathrm{C}), 130.2(\mathrm{CH}), 131.1(\mathrm{C}), 132.7(\mathrm{C})$, $134.8(\mathrm{CH}), 135.4(\mathrm{CH}), 136.1(\mathrm{C}), 146.1(\mathrm{C}), 170.1(\mathrm{C})$. HR-ESI-MS: $\mathrm{m} / \mathrm{z}$ Calcd for $\mathrm{C}_{17} \mathrm{H}_{16} \mathrm{BrClO}_{2} \mathrm{~S},[\mathrm{M}]^{+}$ 399.7145; found 399.7119 .

$3^{\prime}, 4^{\prime}, 5$-Trichloro-[1,1'-biphenyl]-2-yl 2-bromobutanoate (5d), white crystals, m.p: $276-27{ }^{\circ} \mathrm{C} .{ }^{1} \mathrm{H}-\mathrm{NMR}$ $\left(600 \mathrm{MHz}, \mathrm{CDCl}_{3}\right) \delta 7.96(\mathrm{~d}, J=2.3 \mathrm{~Hz}, 1 \mathrm{H}), 7.83(\mathrm{~d}, J=1.9 \mathrm{~Hz}, 1 \mathrm{H}), 7.51-7.43(\mathrm{~m}, 2 \mathrm{H}), 7.40(\mathrm{dd}$, $\left.J_{1}=8.2 \mathrm{~Hz}, J_{2}=2.0 \mathrm{~Hz}, 1 \mathrm{H}\right), 7.33(\mathrm{~d}, J=1.5 \mathrm{~Hz}, 1 \mathrm{H}), 4.20(\mathrm{t}, J=7.0 \mathrm{~Hz}, 1 \mathrm{H}), 2.15-2.20(\mathrm{~m}, 2 \mathrm{H}, \mathrm{Ar}), 1.10$ $(\mathrm{t}, J=8.0 \mathrm{~Hz}, 3 \mathrm{H}) \cdot{ }^{13} \mathrm{C}-\mathrm{NMR}\left(150 \mathrm{MHz}, \mathrm{CDCl}_{3}\right) \delta 10.1\left(\mathrm{CH}_{3}\right), 25.6\left(\mathrm{CH}_{2}\right), 45.4(\mathrm{CH}), 121.1(\mathrm{CH}), 126.5$ $(\mathrm{CH}), 128.1(\mathrm{CH}), 130.2(\mathrm{CH}), 131.2(\mathrm{CH}), 132.7(\mathrm{C}), 135.8(\mathrm{CH}), 136.2(\mathrm{C}), 137.2(\mathrm{C}), 138.5(\mathrm{C}), 141.5(\mathrm{C})$, 148.1 (C), 170.1 (C). HR-ESI-MS: $\mathrm{m} / \mathrm{z}$ Calcd for $\mathrm{C}_{16} \mathrm{H}_{12} \mathrm{BrCl}_{3} \mathrm{O}_{2}$, [M] ${ }^{+}$422.5233; found 422.5289.

5-Chloro-4'-methoxy-[1,1'-biphenyl]-2-yl 2-bromobutanoate (5e), light brown crystal, m.p: $237-238{ }^{\circ} \mathrm{C}$. ${ }^{1} \mathrm{H}-\mathrm{NMR}\left(600 \mathrm{MHz}, \mathrm{CDCl}_{3}\right) \delta 7.98(\mathrm{~d}, J=2.0 \mathrm{~Hz}, 1 \mathrm{H}), 7.65(\mathrm{~d}, J=2.5 \mathrm{~Hz}, 2 \mathrm{H}) 7.49-7.35(\mathrm{~m}, 2 \mathrm{H}), 7.10$ $\left(\mathrm{dd}, J_{1}=8.2 \mathrm{~Hz}, J_{2}=1.5 \mathrm{~Hz}, 2 \mathrm{H}\right), 4.22(\mathrm{t}, J=6.9 \mathrm{~Hz}, 1 \mathrm{H}), 3.93(\mathrm{~s}, 3 \mathrm{H}), 2.08-2.15(\mathrm{~m}, 2 \mathrm{H}, \mathrm{Ar}), 1.10(\mathrm{t}$, $J=8.0 \mathrm{~Hz}, 3 \mathrm{H}) .{ }^{13} \mathrm{C}-\mathrm{NMR}\left(150 \mathrm{MHz}, \mathrm{CDCl}_{3}\right) \delta 10.1\left(\mathrm{CH}_{3}\right), 25.6\left(\mathrm{CH}_{2}\right), 45.4(\mathrm{CH}), 60.2\left(\mathrm{CH}_{3}\right), 116.1(\mathrm{CH})$, $116.5(\mathrm{CH}), 124.5(\mathrm{CH}), 125.3(\mathrm{C}), 128.4(\mathrm{CH}), 130.3(\mathrm{CH}), 131.4(\mathrm{C}), 132.2(\mathrm{CH}), 13.3(\mathrm{CH}), 132.7(\mathrm{C})$, 135.8 (C), 151.2 (C), 170.1 (C). HR-ESI-MS: $m / z$ Calcd for $\mathrm{C}_{17} \mathrm{H}_{16} \mathrm{BrClO}_{3},[\mathrm{M}]^{+} 383.4515$; found 383.4565.

3',5-Dichloro-[1,1'-biphenyl]-2-yl 2-bromobutanoate (5f), white crystal, m.p: $232-233{ }^{\circ} \mathrm{C} .{ }^{1} \mathrm{H}-\mathrm{NMR}$ $\left(600 \mathrm{MHz}, \mathrm{CDCl}_{3}\right) \delta 8.01(\mathrm{~d}, J=2.5 \mathrm{~Hz}, 2 \mathrm{H}), 7.52\left(\mathrm{dd}, J_{1}=7.5 \mathrm{~Hz}, J_{2}=1.9 \mathrm{~Hz}, 1 \mathrm{H}\right), 7.55(\mathrm{t}$, $J=2.0 \mathrm{~Hz}, 1 \mathrm{H}), 7.42-7.41(\mathrm{~m}, 2 \mathrm{H}), 7.34(\mathrm{~d}, J=7.0 \mathrm{~Hz}, 1 \mathrm{H}), 4.22(\mathrm{t}, J=7.0 \mathrm{~Hz}, 1 \mathrm{H}), 2.08-2.15(\mathrm{~m}, 2 \mathrm{H}, \mathrm{Ar})$, $1.10(\mathrm{t}, J=8.0 \mathrm{~Hz} 3 \mathrm{H}) .{ }^{13} \mathrm{C}-\mathrm{NMR}\left(150 \mathrm{MHz}, \mathrm{CDCl}_{3}\right) \delta 10.1\left(\mathrm{CH}_{3}\right), 25.6\left(\mathrm{CH}_{2}\right), 45.4(\mathrm{CH}), 121.1(2 \mathrm{CH})$, 122.4 (CH), $121.9(\mathrm{CH}), 125.2(\mathrm{CH}), 128.7(2 \mathrm{CH}), 130.2(\mathrm{C}), 132.7(\mathrm{C}), 133.2(\mathrm{C}), 134.7(\mathrm{C}), 151.3(\mathrm{C}), 171.2$ (C). HR-ESI-MS: $m / z$ Calcd for $\mathrm{C}_{16} \mathrm{H}_{13} \mathrm{BrCl}_{2} \mathrm{O}_{2}$, [M] ${ }^{+}$388.0861; found 388.0839.

\subsection{Computational Details}

All calculations were performed in Gaussian 09 software [33]. The optimized structures were drawn using Gauss View 5.0 software [34]. The structures of synthesized compounds (5a-f) were optimized with the hybrid functional (B3LYP) of the density functional theory (DFT). B3LYP is a widely used functional for the optimization of organic molecules because the minimization of errors 
in the geometrical parameters is lower for B3LYP compared to that of other density functionals. The split valence basis set developed by Pople'6-311G (d,p) was implemented for molecular orbital descriptions. For further confirmation of these minimum energy structures obtained from optimization (Figure 1), frequency analysis and frontier molecular orbital analysis were done at the same level of theory. During frequency simulations, the harmonic force constant was calculated, which validated the absence of imaginary frequency and justified these as true minima structures. FMOs, reactivity descriptor parameters (ionization potential, electron affinity, chemical hardness, electrophilicity index, electronic chemical potential, and nucleophilicity), and molecular electrostatic potential (MEP) were calculated with the B3LYP/6-311G $(\mathrm{d}, \mathrm{p})$ method. NLO properties including polarizabilities, first hyperpolarizability, and gamma values were calculated with CAM-B3LYP and LC-BLYP with $6-311+G(d, p)$ levels. The best NLO results were obtained by the CAM-B3LYP/6-31+G $(d, p)$ level, so we discussed our results obtained on this level of theory. The nonlinear refractive index was also calculated a with the CAM-B3LYP/6-31+G $(\mathrm{d}, \mathrm{p})$ method.

\section{Conclusions}

In conclusion, a series of 2-bromo-4-chlorophenyl-2-bromobutyrate derivatives (5a-f) were synthesized and frontier molecular orbitals (FMOs) and molecular electrostatic potential (MEP) analysis were done. FMOs analysis revealed that among all the derivatives, $\mathbf{5 c}$ is most reactive, having a HOMO-LUMI band gap of $4.27 \mathrm{eV}$, whereas the HOMO-LUMO band-gap for $5 \mathbf{f}$ was $5.19 \mathrm{eV}$, and was the most stable. The chemical hardness of $5 \mathbf{f}$ displayed the highest value $(2.60 \mathrm{eV})$, whereas $5 \mathbf{c}$ has the lowest value and was chemically soft and reactive. Among all the newly synthesized compounds, $\mathbf{5 d}$ displayed the highest chemical potential value. The molecular electrostatic potential (MEP) investigation gave us the idea of electrophilicity and nucleophilicity of the synthesized compounds, and it was envisaged that depression of electron density is highly dependent on the substituent present on an aromatic ring. The first hyperpolarizability values showed that all synthesized derivatives has a potential non-linear optics (NLO) response, but $5 \mathrm{c}$ has a significant NLO potential due to its large $\beta \mathrm{O}$ (1373.76 au) value.

Author Contributions: U.N., A.M. (Aqsa Mujahid), A.M. (Asim Mansha), M.Z., A.R.S., T.M. and N.K. conceived and designed the experiment and implemented the experiments; N.R. supervised and wrote, reviewed, and edited the manuscript; S.A.A.S., Z.A.Z., and M.N.A. analyzed the data and wrote the original draft, helped in experiments, and contributed reagents/material and analysis tools. All authors have read and agreed to the published version of the manuscript.

Funding: This research received no external funding.

Acknowledgments: The authors would like to acknowledge the Ministry of Higher Education (MOHE) Malaysia for financial support under the Fundamental Research Grant Scheme (FRGS) with sponsorship reference numbers FRGS/1/2019/STG05/UITM/02/9. The authors would also like to acknowledge Universiti Teknologi MARA for the financial support under the reference number 600-IRMI/FRGS 5/3 (424/2019). The data reported herein is part of the M. Phil thesis research work of Usman Nazeer.

Conflicts of Interest: The authors declare no conflict of interest.

\section{References}

1. Tawata, S.; Taira, S.; Kobamoto, N.; Zhu, J.; Ishihara, M.; Toyama, S. Synthesis and antifungal activity of cinnamic acid esters. Biosci. Biotechnol. Biochem. 1996, 60, 909-910. [CrossRef] [PubMed]

2. Harini, S.T.; Kumar, H.V.; Rangaswamy, J.; Naik, N. Synthesis, antioxidant and antimicrobial activity of novel vanillin derived piperidin-4-one oxime esters: Preponderant role of the phenyl ester substituents on the piperidin-4-one oxime core. Bioorg. Med. Chem. Lett. 2012, 22, 7588-7592. [CrossRef] [PubMed]

3. Rainsford, K.D.; Whitehouse, M.W. Anti-inflammatory/anti-pyretic salicylic acid esters with low gastric ulcerogenic activity. Agents Act. 1980, 10, 451-456. [CrossRef] [PubMed]

4. Reddy, Y.S.; Kaki, S.S.; Rao, B.B.; Jain, N.; Vijayalakshm, P. Study on Synthesis, Characterization and Antiproliferative Activity of Novel Diisopropylphenyl Esters of Selected Fatty Acids. J. Oleo Sci. 2016, 65, 81-89. [CrossRef] 
5. Tandon, V.K.; Yadav, D.B.; Singh, R.V.; Chaturvedi, A.K.; Shukla, P.K. Synthesis and biological evaluation of novel (l)- $\alpha$-amino acid methyl ester, heteroalkyl, and aryl substituted 1,4-naphtho quinone derivatives as antifungal and antibacterial agents. Bioorg. Med. Chem. Lett. 2005, 15, 5324-5328. [CrossRef] [PubMed]

6. Rottig, A.; Wenning, L.; Broker, D.; Steinbuchel, A. Fatty acid alkyl esters: Perspectives for production of alternative biofuels. Appl. Microbiol. Biotechnol. 2010, 85, 1713-1733. [CrossRef] [PubMed]

7. Giam, C.S.; Chan, H.S.; Neff, G.S.; Atlas, E.L. Phthalate ester plasticizers: A new class of marine pollutant. Science 1978, 199, 419-421. [CrossRef]

8. Keng, P.S.; Basri, M.; Zakaria, M.R.S.; Rahman, M.A.; Ariff, A.B.; Rahman, R.A.; Salleh, A.B. Newly synthesized palm esters for cosmetics industry. Ind. Crops Prod. 2009, 29, 37-44. [CrossRef]

9. Suarez, G.S.; Massa, N.E.; Jubert, A.H.; Jios, J.L.; Autino, J.C.; Romanelli, G.P. Spectroscopic and theoretical study of 2-acetylphenyl-2-naphthoate. Spectrochim. Acta Part A 2009, 71, 1989-1998. [CrossRef]

10. Yamamura, K.; Ono, S.; Tabushi, I. New liquid crystals having 4, 4'-biphenanthryl core. Tetrahedron Lett. 1988, 29, 1797-1798. [CrossRef]

11. Hohnholz, D.; Schweikart, K.H.; Subramanian, L.R.; Wedel, A.; Wischert, W.; Hanack, M. Synthesis and studies on luminescent biphenyl compounds. Synth. Met. 2000, 110, 141-152. [CrossRef]

12. Bakheit, A.H.H.; Abd-Elgalil, A.A.; Mustafa, B.; Haque, A.; Wani, T.A. Telmisartan. In Profiles of Drug Substances, Excipients and Related Methodology; Academic Press: San Diego, CA, USA, 2015.

13. Aronson, J. Meyler's Side Effects of Drugs, 16th ed.; Elsevier: Amsterdam, The Netherlands, 2016.

14. Mutahir, S.; Jonczyk, J.; Bajda, M.; Khan, I.U.; Khan, M.A.; Ullah, N.; Ashraf, M.; Riaz, S.; Hussain, S.; Yar, M. Novel biphenyl bis-sulfonamides as acetyl and butyrylcholinesterase inhibitors: Synthesis, biological evaluation and molecular modeling studies. Bioorg. Chem. 2016, 64, 13-20. [CrossRef] [PubMed]

15. Ding, Y.; Mao, L.; Xu, D.; Xie, H.; Yang, L.; Xu, H.; Yang, L.; Xu, H.; Geng, W.; Gao, Y.; et al. C-Aryl glucoside SGLT2 inhibitors containing a biphenyl motif as potential anti-diabetic agents. Bioorgan. Med. Chem. Lett. 2015, 25, 2744-2748. [CrossRef] [PubMed]

16. Cincinelli, R.; Zwick, V.; Musso, L.; Zuco, V.; De Cesare, M.; Zunino, F.; Simoes-Pires, C.; Nussiro, A.; Giannini, G.; Cuendet, M.; et al. Biphenyl-4-yl-acrylohydroxamic acids: Identification of a novel indolyl-substituted HDAC inhibitor with antitumor activity. Eur. J. Med. Chem. 2016, 112, 99-105. [CrossRef] [PubMed]

17. Kong, X.W.; Zhang, Y.H.; Dai, L.; Ji, H.; Lai, Y.S.; Peng, S.X. Synthesis and biological evaluation ofnitric oxide-releasing sixalkoxyl biphenyl derivatives as anticancer agents. Chin. Chem. Lett. 2008, 19, 149-152. [CrossRef]

18. Dong, J.; Pan, X.; Wang, J.; Su, P.; Zhang, L.; Wei, F.; Zhang, J. Synthesis and biological evaluation of novel aromatic-heterocyclic biphenyls as potent anti-leukemia agents. Eur. J. Med. Chem. 2015, 101, 780-789. [CrossRef]

19. Brudeli, B.; Andressen, K.W.; Moltzau, L.R.; Nilsen, N.O.; Levy, F.O.; Klaveness, J. Acidic biphenyl derivatives: Synthesis and biological activity of a new series of potent 5-HT4 receptor antagonists. Bioorg. Med. Chem. 2013, 21, 7134-7145. [CrossRef]

20. Gargano, E.M.; Perspicace, E.; Carotti, A.; Marchais-Oberwinkler, S.; Hartmann, R.W. Addressing cytotoxicity of 1,4-biphenyl amide derivatives: Discovery of new potent and selective $17 \beta$-hydroxysteroid dehydrogenase type 2 inhibitors. Bioorg. Med. Chem. Lett. 2016, 26, 21-24. [CrossRef]

21. Rizwan, K.; Zubair, M.; Rasool, N.; Ali, S.; Zahoor, A.F.; Rana, U.A.; Jaafar, H.Z. Regioselective synthesis of 2-(bromomethyl)-5-aryl-thiophene derivatives via palladium (0) catalyzed suzuki cross-coupling reactions: As antithrombotic and haemolytically active molecules. Chem. Cent. J. 2014, 8, 1-8. [CrossRef]

22. Del Rio, N.; Baceiredo, A.; Saffon-Merceron, N.; Hashizume, D.; Lutters, D.; Müller, T.; Kato, T. A Stable Heterocyclic Amino (phosphanylidene-o4-phosphorane) Germylene. Angew. Chem. Int. Ed. 2016, 55, 4753-4758. [CrossRef]

23. Gull, Y.; Rasool, N.; Noreen, M.; Nasim, F.U.H.; Yaqoob, A.; Kousar, S.; Islam, M. Efficient synthesis of 2-amino-6-arylbenzothiazoles via Pd (0) Suzuki cross coupling reactions: Potent urease enzyme inhibition and nitric oxide scavenging activities of the products. Molecules 2013, 18, 8845-8857. [CrossRef] [PubMed]

24. Nayak, P.K.; Periasamy, N. Calculation of electron affinity, ionization potential, transport gap, optical band gap and exciton binding energy of organic solids using 'solvation' model and DFT. Org. Electron. 2009, 10, 1396-1400. [CrossRef] 
25. Arshad, M.N.; Asiri, A.M.; Alamry, K.A.; Mahmood, T.; Gilani, M.A.; Ayub, K.; Birinji, A.S. Synthesis, crystal structure, spectroscopic and density functional theory (DFT) study of N-[3-anthracen-9-yl-1-(4bromophenyl)-allylidene]-N-benzenesulfonohydrazine. Spectrochim. Acta Part A 2015, 142, 364-374. [CrossRef] [PubMed]

26. Arshad, M.N.; Bibi, A.; Mahmood, T.; Asiri, A.M.; Ayub, K. Synthesis, crystal structures and spectroscopic properties of triazine-based hydrazone derivatives; A comparative experimental-theoretical study. Molecules 2015, 20, 5851-5874. [CrossRef] [PubMed]

27. Mebi, C.A. DFT study on structure, electronic properties, and reactivity of cis-isomers of [(NC5H4-S) 2 Fe (CO) $)_{2}$ ]. J. Chem. Sci. 2011, 123, 727-731. [CrossRef]

28. Parr, R.G.; Szentpaly, L.V.; Liu, S. Electrophilicity index. J. Am. Chem. Soc. 1999, 121, 1922-1924. [CrossRef]

29. Ahmed, M.N.; Yasin, K.A.; Ayub, K.; Mahmood, T.; Tahir, M.N.; Khan, B.A.; Hafeez, M.; Ahmed, M. Click one pot synthesis, spectral analyses, crystal structures, DFT studies and brine shrimp cytotoxicity assay of two newly synthesized 1,4,5-trisubstituted 1,2,3-triazoles. J. Mol. Struct. 2016, 1106, 430-439. [CrossRef]

30. Marder, S.R. Organic nonlinear optical materials: Where we have been and where we are going. Chem. Commun. 2006, 2, 131-134. [CrossRef]

31. Champagne, B.; Plaquet, A.; Pozzo, J.L.; Rodriguez, V.; Castet, F. Nonlinear Optical Molecular Switches as Selective Cation Sensors. J. Am. Chem. Soc. 2012, 134, 8101-8103. [CrossRef]

32. Tarazkar, M.; Romanov, D.A.; Levis, R.J. Theoretical study of second-order hyperpolarizability for nitrogen radical cation. J. Phys. B At. Mol. Opt. Phys. 2015, 48, 094019. [CrossRef]

33. Frisch, M.; Trucks, G.; Schlegel, H.; Scuseria, G.; Robb, M.; Cheeseman, J.; Scalmani, G.; Barone, V.; Mennucci, B.; Petersson, G. Gaussian 09, Rev. B. 01; Gaussian Inc.: Wallingford, CT, USA, 2010.

34. Dennington, R.; Todd, K.; John, M. Gauss View, Version 5; Semichem Inc.: Shawnee Mission, KS, USA, 2009.

Sample Availability: Samples of the compounds are not available from the authors.

(C) 2020 by the authors. Licensee MDPI, Basel, Switzerland. This article is an open access article distributed under the terms and conditions of the Creative Commons Attribution (CC BY) license (http://creativecommons.org/licenses/by/4.0/). 